\title{
Value-based sleep and breathing: health economic aspects of obstructive sleep apnea
}

\author{
Emerson M. Wickwire ${ }^{1 *}$
}

${ }^{1}$ Sleep Disorders Center, Division of Pulmonary and Critical Care Medicine, Department of Medicine, University of Maryland School of Medicine, Baltimore, MD, USA; Department of Psychiatry, University of Maryland School of Medicine, Baltimore, MD, USA

\begin{abstract}
Obstructive sleep apnea (OSA) is a common and costly medical condition. Untreated OSA is associated with numerous and welldocumented adverse health consequences including depression, diabetes, cardiovascular disease, and premature death. In addition to these health consequences, untreated OSA is also associated with substantial costs borne by patients, payers, the health system, and society at large. Perhaps more importantly, evidence suggests that OSA treatment is associated with positive economic benefit. The purpose of this brief review is to introduce economic aspects of OSA, including the potential economic benefit of OSA treatment.
\end{abstract}

\section{Keywords}

Sleep, sleep apnea, treatment, economics, costs, cost-effectiveness

\section{Peer Review}

The peer reviewers who approve this article are:

1. Reena Mehra, Sleep Disorders Research Program, Sleep Disorders Center, Neurological Institute, Cleveland Clinic, Cleveland, USA

Competing interests: No competing interests were disclosed.

2. Najib Ayas, University of British Columbia, Vancouver, Canada Competing interests: No competing interests were disclosed.

*Corresponding author: Emerson M. Wickwire (ewickwire@som.umaryland.edu)

Competing interests: EMW's institution has received research funding from the AASM Foundation, Department of Defense, Merck, and ResMed. EMW has served as a scientific consultant to DayZz, Eisai, Merck, and Purdue and is an equity shareholder in WellTap.

Grant information: The authors declare that no grants were involved in supporting this work.

Copyright: $@ 2021$ Wickwire EM et al. This is an open access article distributed under the terms of the Creative Commons Attribution License, which permits unrestricted use, distribution, and reproduction in any medium, provided the original work is properly cited.

How to cite this article: Wickwire EM. Value-based sleep and breathing: health economic aspects of obstructive sleep apnea. Faculty Reviews 2021 10:(40) https://doi.org/10.12703/r/10-40

Published: 19 Apr 2021, Faculty Reviews 10:(40) https://doi.org/10.12703/r/10-40 


\section{Introduction}

Obstructive sleep apnea (OSA) is a common and costly medical condition. The health consequences of OSA include increased risk for cardiovascular disease $\mathrm{e}^{1-3}$, stroke $^{4}$, metabolic syndrome $e^{5,6}$, reduced quality of $\operatorname{life}^{7}$, and premature death ${ }^{8,9}$. Approximately $14 \%$ of men and $5 \%$ of women between the ages of 30 and 70 years in the United States suffer moderate to severe $\mathrm{OSA}^{10}$, with 936 million individuals estimated to suffer OSA worldwide ${ }^{11}$. In part because of rising rates of obesity, the prevalence of the disorder is increasing ${ }^{12,13}$.

Beyond well-documented adverse health outcomes, OSA incurs dramatic economic costs borne by patients, payers, employers, and society ${ }^{14}$. Yet, despite widespread acknowledgment that OSA is associated with substantial economic burden, relatively little research has evaluated economic aspects of OSA treatments ${ }^{15}$. In the modern healthcare climate of rising costs on the one hand and limited resources on the other, such knowledge is essential for payers and policy-makers who seek to make evidence-based decisions regarding allocation of scarce healthcare resources. To this end, the purpose of the present paper is to introduce key health economic concepts pertaining to OSA and to very briefly summarize the evidence to date regarding health economic aspects of OSA.

\section{Very brief introduction into health economic aspects of obstructive sleep apnea}

\section{Costs of obstructive sleep apnea}

Several years ago, the American Academy of Sleep Medicine commissioned a white paper that estimated total societal-level costs of OSA to exceed $\$ 150$ billion per year in the United States alone ${ }^{16}$. Broadly speaking, these OSA costs can be divided into three categories: direct costs, indirect costs, and health-related quality of life (HrQOL). Direct costs of OSA include costs of OSA diagnosis and management, including provider consultation, sleep apnea testing, device and supply costs (e.g. continuous positive airway pressure [CPAP] or oral appliance [OA] therapy), prescription medications, and so on. Indirect costs include costs unrelated to direct OSA care that are nonetheless attributable to OSA, such as increased healthcare utilization (HCU) for non-OSA conditions, diminished workplace productivity (e.g. absenteeism or presenteeism [being physically present but less productive than expected]), and increased risk of accidents and errors including motor vehicle collisions (MVCs). In the AASM white paper, the greatest costs associated with OSA were lost workplace productivity ( $\$ 86.9$ billion), increased HCU ( $\$ 30$ billion), MVCs (\$26.2 billion), and workplace accidents and injuries (\$6.5 billion $)^{16}$. Although total societal-level costs are often cited to demonstrate the costs associated with OSA and other sleep disorders, it is important to realize that each of these costs is primarily borne by different stakeholders ${ }^{17}$.

\section{Health-related quality of life}

In addition to direct and indirect costs that can be clearly monetized, HrQOL is a key economic outcome ${ }^{18,19}$. HrQOL includes both general as well as disease-specific outcomes, which can be measured using various tools. Common general HrQOL measures include the PROMIS, developed as part of the National Institutes of Health Roadmap ${ }^{20}$, Short-Form 36 $(\mathrm{SF}-36)^{21}$, EuroQol-5D ${ }^{22}$, and others; the Functional Outcomes of Sleep Questionnaire (FOSQ $)^{23}$ is an example of an OSA-specific measure of HrQOL. The most common economic metric to quantify HrQOL is the quality adjusted life year (QALY). QALYs represent the product of HrQOL and time (i.e. [quality on $0-1$ utility scale] * [time in years]) and thus provide researchers and decision-makers with a standardized metric to compare return-on-investment across diverse disease states, such as in cost-effectiveness analyses (CEAs) ${ }^{15}$. In CEAs, cost-effectiveness is determined based on the ratio of quality to cost, which is known as the incremental cost-effectiveness ratio (ICER). As a measure of value, ICERs reflect the cost per QALY. A given health system or payer determines a willingness to pay (WTP) for a QALY. For example, in the US, a cost of \$50,000 per QALY is a generally accepted threshold for cost-effectiveness. Over the past three-plus decades, a preponderance of evidence demonstrates that untreated OSA worsens HrQOL and OSA treatments improve HrQOL and are generally cost-effective ${ }^{14}$.

Economic perspective: value is in the eye of the beholder The sleep medicine ecosystem includes diverse stakeholders such as patients, payers, providers, health systems, and equipment manufacturers, just to name a few. Each of these stakeholders incurs different costs (and potentially cost savings or revenues) so perceives the value of sleep differently. For example, patients desire improved quality of life, such as increased energy for work or leisure activities, as well as ease of care experience. Payers want to reduce costs of care delivery, which is directly related to profits. Providers want valid, reliable, and easy-to-administer testing and treatment options, and so on. Table 1 presents common economic perspectives in sleep medicine.

\section{Diagnosing and treating obstructive sleep apnea: economic considerations}

From an economic perspective, the diagnosis of OSA involves two broad components: provider time and sleep apnea testing. As a result, the most expensive costs would include a face-to-face physician encounter, in regulated hospital space, and in-lab diagnostic polysomnography with an additional in-lab CPAP titration. At the other extreme, diagnostic costs could

Table 1. Economic perspectives in sleep medicine.

\begin{tabular}{|c|c|}
\hline Perspective & Value-based outcome \\
\hline Patient & Quality of life, ease of treatment experience \\
\hline Payer & Cost savings for increased profitability \\
\hline Employer & Workplace productivity, accident risk \\
\hline Health system & Revenue (margin), population health \\
\hline Society & $\begin{array}{l}\text { Aggregated costs and health economic } \\
\text { outcomes }\end{array}$ \\
\hline
\end{tabular}


include consultation with a mid-level provider, via telehealth, and home sleep apnea testing (HSAT) without a separate titration study. Like OSA diagnosis, OSA treatment costs include two components: initial device and equipment (e.g. CPAP) and ongoing supply costs. Furthermore, it is important to realize the competing interests in these OSA pathways: cost savings (a positive) from the payer's perspective results in reduced revenue (a negative) from the health system's perspective or decreased reimbursement (a negative) from the provider's perspective. As one example, consider findings from an economic analysis of a multi-site clinical trial designed to compare in-lab versus at-home approaches to OSA diagnosis and treatment ${ }^{24}$. Kim and colleagues found that payer costs were reduced by $\$ 264$ over three months when patients were treated within the at-home arm (as opposed to the in-lab arm). By contrast, provider operating margin was reduced from $\$ 142$ to $-\$ 161$ under these same conditions. Finally, time horizon is an important consideration: most OSA treatment costs are front-loaded, but OSA cost reductions might not be realized immediately.

As healthcare transitions from volume-based care to value-based care, alternative payment models (APMs) have been employed in numerous disease states. To date, APMs have not yet impacted sleep medicine in the US in a meaningful way. Nonetheless, bundled payments and shared risk are likely to impact the field of sleep medicine sooner rather than later. Within a value-based framework, both maximizing quality and minimizing cost are essential. Such matters, including cost-shifting between stakeholders, have been discussed in detail elsewhere ${ }^{17}$.

\section{Economic impact of obstructive sleep apnea treatments}

Relative to thousands of studies that evaluated pathophysiologic, clinical, and epidemiologic aspects of OSA, few studies have considered the economic impact of OSA treatments. Two prior reviews primarily considered costs of untreated OSA ${ }^{25}$ or included only a very limited number $(n=5)$ of studies that examined the impact of OSA treatment on $\mathrm{HCU}^{26}$. More recently, our group published a systematic review of the impact of OSA treatments on monetized economic outcomes. Results demonstrated that 15 of 17 comparisons reported a positive economic benefit from OSA treatment (results are included in Table 2) ${ }^{14}$. Since that time, two additional studies have found a beneficial effect on PAP. Kirsch and colleagues ${ }^{27}$ analyzed data from a large health system in the Southeastern US. These investigators found a linear dose-response relationship between

Table 2. Summary of empirical studies examining the impact of OSA treatments on monetized economic outcomes.

\begin{tabular}{|c|c|c|c|c|c|}
\hline Ref & Sample & Design & $\begin{array}{l}\text { OSA } \\
\text { treatment }\end{array}$ & $\begin{array}{l}\text { Economic } \\
\text { outcome }\end{array}$ & Key findings \\
\hline 28 & $\begin{array}{l}N=34, M \text { age }=48 y \\
100 \% \text { men in Canada }\end{array}$ & $\begin{array}{l}\text { Retrospective cohort } \\
\text { study }\end{array}$ & CPAP & $\begin{array}{l}\text { Outpatient } \\
\text { visits, physician } \\
\text { costs }\end{array}$ & $\begin{array}{l}\text { Vs. 1y prediagnosis, CPAP reduced outpatient } \\
\text { visits ( } 1.03 \text { visits) and physician costs by } \$ 14.23 \\
\text { over } 5 y\end{array}$ \\
\hline 29 & $\begin{array}{l}N=344, M \text { age }=49 y \\
100 \% \text { men in Canada }\end{array}$ & $\begin{array}{l}\text { Prospective cohort } \\
\text { study }\end{array}$ & $\begin{array}{l}\text { CPAP or } \\
\text { BPAP }\end{array}$ & $\begin{array}{l}\text { Physician costs, } \\
\text { hospitalizations }\end{array}$ & $\begin{array}{l}\text { Vs. } 2 y \text { prediagnosis and among adherers, CPAP } \\
\text { reduced physician costs and hospitalizations over } \\
2 y\end{array}$ \\
\hline 30 & $\begin{array}{l}\mathrm{N}=414, \mathrm{M} \text { age }=49 \mathrm{y} \\
\text { in Canada }\end{array}$ & $\begin{array}{l}\text { Retrospective cohort } \\
\text { study }\end{array}$ & $\begin{array}{l}\text { CPAP or } \\
\text { BPAP }\end{array}$ & $\begin{array}{l}\text { Outpatient } \\
\text { visits, physician } \\
\text { costs }\end{array}$ & $\begin{array}{l}\text { Vs. 1y prediagnosis, CPAP reduced outpatient } \\
\text { visits and physician costs by } \$ 37.26 \text { over } 2 y\end{array}$ \\
\hline 31 & $\begin{array}{l}N=15,424, M \text { age }= \\
48 y, 70 \% \text { men in USA }\end{array}$ & $\begin{array}{l}\text { Retrospective cohort } \\
\text { study }\end{array}$ & CPAP & $\begin{array}{l}\text { Total costs, } \\
\text { all-cause and } \\
\text { OSA-related } \\
\text { hospitalizations }\end{array}$ & $\begin{array}{l}\text { Vs. 1y prediagnosis, CPAP reduced total costs } \\
\text { ( } \$ 792 \text { vs. } \$ 883 \text { ) and rates of all-cause (19\% } \\
\text { vs. } 24.2 \%) \text { and OSA-related (8\% vs. } 11.3 \%) \\
\text { hospitalizations over } 2 \text { y }\end{array}$ \\
\hline 32 & $\begin{array}{l}\mathrm{N}=22,361 \mathrm{w} / \mathrm{OSA}, \mathrm{M} \\
\text { age }=67.2 \mathrm{y}, 53 \% \text { men } \\
\text { in US }\end{array}$ & $\begin{array}{l}\text { Retrospective cohort } \\
\text { study }\end{array}$ & CPAP & Total costs & $\begin{array}{l}\text { Vs. 1y prediagnosis, CPAP adherence reduced } \\
\text { total costs }\end{array}$ \\
\hline 33 & $\begin{array}{l}\mathrm{N}=86, \mathrm{M} \text { age }= \\
50.7 \mathrm{y}, 82.3 \% \text { men in } \\
\text { US }\end{array}$ & Multicenter RCT & CPAP, OA & $\begin{array}{l}\text { QALY, total } \\
\text { costs }\end{array}$ & $\begin{array}{l}\text { CPAP was more clinically effective, but based on } \\
\text { cost per QALY, OA was more cost-effective at } 12 \\
\text { months ( } € 33.701 \text { [- } € 191.106 \text { to } € 562.271] \text { per } \\
\text { QALY gained) }\end{array}$ \\
\hline 34 & $\begin{array}{l}\mathrm{N}=248, \mathrm{M} \text { age }=44 \mathrm{y} \\
99 \% \text { men commercial } \\
\text { drivers in USA }\end{array}$ & $\begin{array}{l}\text { Retrospective cohort } \\
\text { study }\end{array}$ & $\begin{array}{l}\text { CPAP or } \\
\text { BPAP }\end{array}$ & Total costs & $\begin{array}{l}\text { Vs. 1y prediagnosis, CPAP reduced HCU costs } \\
\text { over 2y (y1: } \$ 3,062 ; \mathrm{y} 2: \$ 3,465)\end{array}$ \\
\hline 35 & $\begin{array}{l}\mathrm{N}=30,719, \mathrm{M} \text { age } \\
=67.1 \mathrm{y}, 43 \% \text { men in } \\
\text { USA }\end{array}$ & $\begin{array}{l}\text { Retrospective cohort } \\
\text { study }\end{array}$ & CPAP & Costs & $\begin{array}{l}\text { Vs. those not tested, clinically diagnosed, and } \\
\text { not treated }(\$ 12,080 / \text { quarter }[\$ 10,759 \text { in } 2010]) \text {, } \\
\text { costs were lowest for those tested, diagnosed, and } \\
\text { treated }(\$ 6,465 / \text { quarter }[\$ 5,758 \text { in } 2010])\end{array}$ \\
\hline
\end{tabular}




\begin{tabular}{|c|c|c|c|c|c|}
\hline Ref & Sample & Design & $\begin{array}{l}\text { OSA } \\
\text { treatment }\end{array}$ & $\begin{array}{l}\text { Economic } \\
\text { outcome }\end{array}$ & Key findings \\
\hline 36 & $\begin{array}{l}\mathrm{N}=19,438,78 \% \text { men } \\
\text { in Denmark }\end{array}$ & $\begin{array}{l}\text { Retrospective cohort } \\
\text { study }\end{array}$ & $\begin{array}{l}\text { CPAP, } \\
\text { UPPP }\end{array}$ & Total costs & $\begin{array}{l}\text { Vs. } 2 y \text { prediagnosis, neither CPAP nor UPPP } \\
\text { reduced HCU costs over } 2 y\end{array}$ \\
\hline 37 & $\begin{array}{l}\mathrm{N}=1,098, \mathrm{M} \text { age }= \\
55.7 \mathrm{y}, 63 \% \text { men in US }\end{array}$ & $\begin{array}{l}\text { Retrospective cohort } \\
\text { study }\end{array}$ & CPAP & $\begin{array}{l}\text { Acute care } \mathrm{HCU} \\
\text { and costs }\end{array}$ & $\begin{array}{l}\text { CPAP adherence reduced inpatient }(\mathrm{RR}=0.92 \text {, } \\
95 \% \mathrm{Cl}: 0.86-0.98) \text { and overall acute care visits } \\
\text { (RR }=0.96,95 \% \mathrm{Cl}: 0.92-0.99) \text {. Among CPAP } \\
\text { adherers, fewer ED visits and inpatient stays were } \\
\text { observed. }\end{array}$ \\
\hline 37 & $\begin{array}{l}\mathrm{N}=278, \mathrm{M} \text { age }=71 \mathrm{y} \\
79 \% \text { men in UK }\end{array}$ & Multi-center RCT & APAP & $\begin{array}{l}\text { CEA HrQOL: } \\
\text { EQ-5D and } \\
\text { SF-6D }\end{array}$ & $\begin{array}{l}\text { Vs. untreated OSA, APAP was associated with } \\
\text { 0.018 QALYs gained per SF-6D, but no gains per } \\
\text { EQ-5D. APAP reduced costs (-\$61 [-£35 in } 2014 \\
\text { GBP]) over 1y and was marginally cost-effective. }\end{array}$ \\
\hline 38 & $\begin{array}{l}\mathrm{N}=82, \mathrm{M} \text { age }=55 \mathrm{y} \\
82 \% \text { men in Sweden }\end{array}$ & $\begin{array}{l}\text { Retrospective cohort } \\
\text { study }\end{array}$ & CPAP & Hospital costs & $\begin{array}{l}\text { Vs. 2y prediagnosis, CPAP reduced CVPD-related } \\
\text { hospitalization costs }(\$ 80,680 \text { vs. } \$ 11,134) \text { over } 2 y\end{array}$ \\
\hline 39 & $\begin{array}{l}\mathrm{N}=740 \text { children }<18 \mathrm{y} \\
\mathrm{M} \text { age }=5.6 \mathrm{y}, 37 \% \\
\text { boys in Israel }\end{array}$ & $\begin{array}{l}\text { Prospective, } \\
\text { longitudinal case- } \\
\text { control study }\end{array}$ & $T \& A$ & Total costs & $\begin{array}{l}\text { Vs. 1y prediagnosis, CPAP reduced total costs } \\
(32.5 \% ; P<0.0004) \text { over 1y }\end{array}$ \\
\hline
\end{tabular}

APAP, automatic positive airway pressure; BPAP, bilevel positive airway pressure; CEA, cost-effectiveness analysis; CPAP, continuous positive airway pressure; CVPD, cardiovascular and pulmonary disease; ED, emergency department; EQ-5D, European Quality of Life 5 Dimension; HCU, healthcare utilization; HrQOL, health-related quality of life; OA, oral appliance; OSA, obstructive sleep apnea; QALY, quality adjusted life year; RCT, randomized controlled trial; RR, rate ratio; SF-6D, Short Form questionnaire-6 Dimensions; T\&A, adenotonsillectomy; UPPP, uvulopalatopharyngoplasty

objective CPAP adherence data and acute healthcare costs, including reductions in inpatient stays and acute care visits. A particular strength of this study was the use of objective CPAP adherence data, which enables the evaluation of dose-response effects. At the same time, although this study controlled for baseline differences between adherence groups, it was limited in its approach to control for the "healthy user effect" over time (i.e. that CPAP adherence is associated with positive health behaviors $)^{40,41}$, which might have contributed to the positive findings. Similarly, Chhatre and colleagues analyzed data from a large national Medicare administrative claims database ${ }^{32}$. When the authors used CPAP machine charges as a proxy for objective CPAP use, CPAP was associated with reduced total costs. Interestingly, de Vries and colleagues ${ }^{33}$ found OA therapy more cost-effective than CPAP in terms of QALYs, but not in terms of reduction in apnea-hypopnea index, over 12 months. Results of these and other studies examining the economic impact of OSA treatments, reflecting a non-systematic update since our prior systematic review ${ }^{14}$, are summarized in Table 2.

\section{Socioeconomic aspects of obstructive sleep apnea}

Racial and socioeconomic factors have been identified as an important determinant of OSA and OSA outcomes. For example, relative to whites, blacks suffer higher rates of OSA but are less likely to be diagnosed ${ }^{42}$. Evidence suggests that such racial sleep disparities might underlie racial disparities in chronic disease outcomes, such as cardiovascular disease and diabetes ${ }^{43}$. Relative to whites, blacks are also less likely to adhere to CPAP therapy ${ }^{44}$, and low socioeconomic status (SES) and neighborhood of residence have also been associated with poorer CPAP adherence ${ }^{45,46}$. These results further support a link between OSA disparities and health disparities. In recognition of the importance of sleep disparities in overall health disparities, the National Institutes of Health recently hosted a workshop and identified research needs; a summary report has been published elsewhere and is recommended for review ${ }^{47}$.

\section{Future research directions}

Our most important recommendation is to include economic outcomes in OSA clinical trials and sleep research more broadly. Public-private partnerships are likely to be especially fruitful in this regard. Second, in light of the high rates of comorbidity of OSA with numerous medical and psychiatric conditions (e.g. cardiovascular disease, depression, and neurodegenerative disorders, including Alzheimer's disease), it will be important to evaluate economic aspects of OSA within various disease subpopulations. Disentangling the effects of OSA relative to the often better studied comorbid conditions, such as cardiovascular disease, is methodologically challenging yet vital $^{48}$. Third, it is essential to adopt the employer's perspective when assessing the economic impact of OSA. It is notable that the majority of OSA-related costs are borne by employers, yet very few studies have considered economic aspects of OSA from the employer's perspective. Fourth, given the positive economic impact of CPAP adherence, much greater insight is needed regarding the costs and effectiveness of interventions to improve CPAP adherence ${ }^{14,48,49}$. Finally, given the very rapid technological advancements in OSA diagnosis and treatment, it will be important to evaluate the economic impact of telehealth and remote monitoring for OSA. This recommendation is especially important given the impact of the COVID-19 pandemic in terms of clinical care and rapid adoption of telehealth approaches. Additional actionable recommendations to advance understanding regarding the health economic aspects of OSA are presented in Table 3. 
Table 3. Recommendations for future research in OSA.

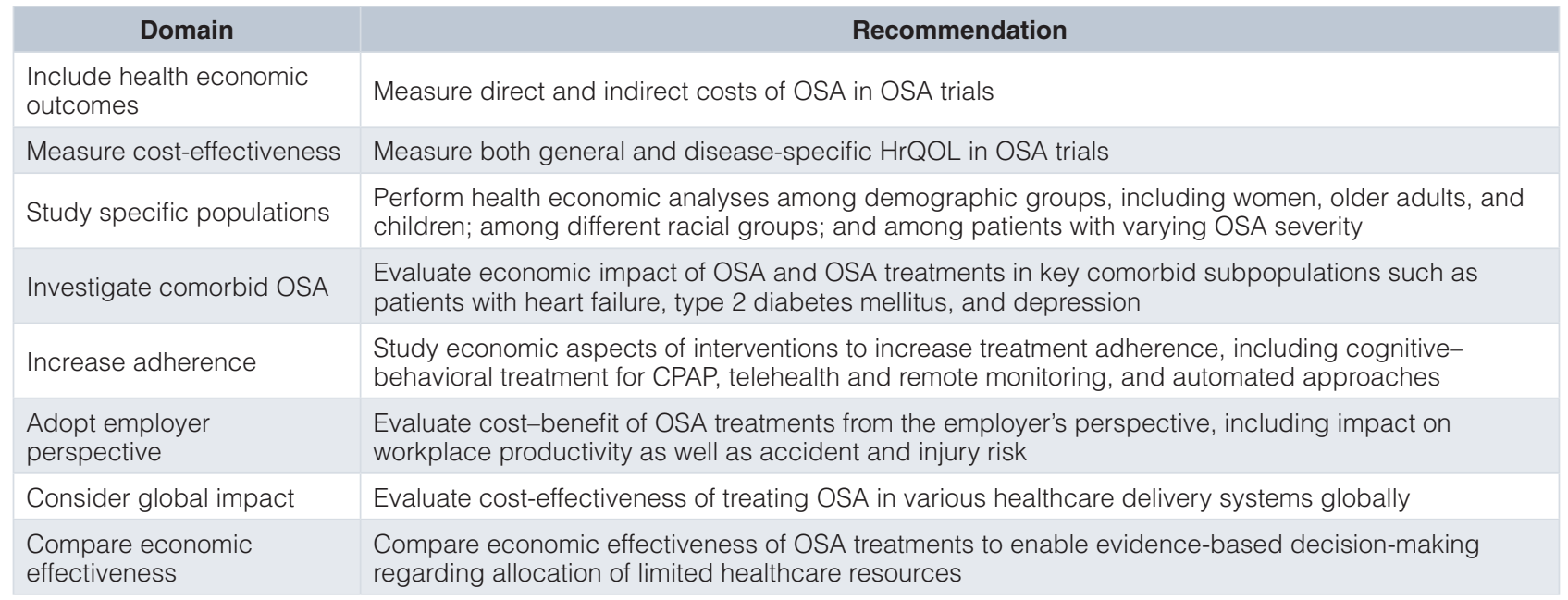

CPAP, continuous positive airway pressure; HrQOL, health-related quality of life; OSA, obstructive sleep apnea

\section{Conclusions}

In summary, OSA incurs significant economic costs borne by a wide range of stakeholders including patients, payers, health systems, industry partners, and others. Although important questions remain unanswered, a small but considerable body of evidence suggests that the diagnosis and treatment of OSA is associated with positive economic benefit. Our most important recommendations are for researchers to include economic endpoints in all OSA clinical trials and to adopt the economic perspectives of multiple stakeholders in the sleep medicine ecosystem. In the modern healthcare climate of rising costs on one hand and limited resources on the other, economic aspects of care will become increasingly important determinants of health policy and resource allocation.
1. Konecny T, Kuniyoshi FHS, Orban M, et al.: Under-diagnosis of sleep apnea in patients after acute myocardial infarction. J Am Coll Cardiol. 2010; 56(9): 742-3. PubMed Abstract | Publisher Full Text | Free Full Text

2. Mehra R, Benjamin EJ, Shahar E, et al:: Association of nocturnal arrhythmias with sleep-disordered breathing: The Sleep Heart Health Study. Am J Respir Crit Care Med. 2006; 173(8): 910-6.

PubMed Abstract | Publisher Full Text | Free Full Text

3. Peppard PE, Young T, Palta M, et al.: Prospective study of the association between sleep-disordered breathing and hypertension. N Engl J Med. 2000; 342(19): 1378-84.

PubMed Abstract | Publisher Full Text

4. Yaggi HK, Concato J, Kernan WN, et al.: Obstructive sleep apnea as a risk factor for stroke and death. N Engl J Med. 2005; 353(19): 2034-41. PubMed Abstract | Publisher Full Text

5. Punjabi NM, Shahar E, Redline S, et al:: Sleep-disordered breathing, glucose intolerance, and insulin resistance: The Sleep Heart Health Study. Am J Epidemiol. 2004; 160(6): 521-30. PubMed Abstract | Publisher Full Text

6. Reichmuth KJ, Austin D, Skatrud JB, et al.: Association of sleep apnea and type II diabetes: A population-based study. Am J Respir Crit Care Med. 2005; 172(12): 1590-5.

PubMed Abstract | Publisher Full Text | Free Full Text |

Faculty Opinions Recommendation

7. Finn L, Young T, Palta M, et al:: Sleep-disordered breathing and self-reported general health status in the Wisconsin Sleep Cohort Study. Sleep. 1998; 21(7): 701-6.

PubMed Abstract | Publisher Full Text
8. Marshall NS, Wong KKH, Cullen SRJ, et al:: Sleep apnea and 20-year followup for all-cause mortality, stroke, and cancer incidence and mortality in the Busselton Health Study cohort. J Clin Sleep Med. 2014; 10(4): 355-62. PubMed Abstract | Publisher Full Text | Free Full Text

9. Punjabi NM, Caffo BS, Goodwin JL, et al:: Sleep-disordered breathing and mortality: A prospective cohort study. PLoS Med. 2009; 6(8): e1000132. PubMed Abstract | Publisher Full Text | Free Full Text | Faculty Opinions Recommendation

10. CPeppard PE, Young T, Barnet JH, et al.: Increased prevalence of sleepdisordered breathing in adults. Am J Epidemiol. 2013; 177(9): 1006-14. PubMed Abstract | Publisher Full Text | Free Full Text | Faculty Opinions Recommendation

11. Benjafield AV, Ayas NT, Eastwood PR, et al:: Estimation of the global prevalence and burden of obstructive sleep apnoea: A literature-based analysis. Lancet Respir Med. 2019; 7(8): 687-98. PubMed Abstract | Publisher Full Text | Free Full Text | Faculty Opinions Recommendation

12. Namen AM, Dunagan DP, Fleischer A, et al.: Increased physician-reported sleep apnea: The National Ambulatory Medical Care Survey. Chest. 2002; 121(6): apnea: The

PubMed Abstract | Publisher Full Text

13. Ford ES, Wheaton AG, Cunningham TJ, et al:: Trends in outpatient visits for insomnia, sleep apnea, and prescriptions for sleep medications among US adults: Findings from the National Ambulatory Medical Care survey 1999-2010. Sleep. 2014; 37(8): 1283-93.

PubMed Abstract | Publisher Full Text | Free Full Text 
14. Wickwire EM, Albrecht JS, Towe MM, et al:: The Impact of Treatments for OSA on Monetized Health Economic Outcomes: A Systematic Review. Chest. 2019; 155(5): 947-61. PubMed Abstract | Publisher Full Text

15. Mohit B, Cohen JT: Trends of cost-effectiveness studies in sleep medicine. Sleep Med. 2019; 53: 176-80.

PubMed Abstract | Publisher Full Text

16. American Academy of Sleep Medicine: Hidden health crisis costing America billions: Underdiagnosing and undertreating obstructive sleep apnea draining healthcare system. Frost and Sullivan; 2016.

Reference Source

17. Wickwire EM, Verma T: Value and Payment in Sleep Medicine. J Clin Sleep Med 2018; 14(5): 881-4

PubMed Abstract | Publisher Full Text | Free Full Text

18. Neumann PJ, Sanders GD, Russell LB, et al.: Cost-effectiveness in health and medicine. 2nd ed. Oxford University Press; 2017. Reference Source

19. Muennig $\mathrm{P}$, Bounthavong M: Cost-effectiveness analysis in health: A practical approach, 3rd Edition. Jossey-Bass (Wiley); 2016 Reference Source

20. Hanmer J, Feeny D, Fischhoff B, et al.: The PROMIS of QALYs. Health Qual Life Outcomes. 2015; 13: 122.

PubMed Abstract | Publisher Full Text | Free Full Text

21. Ware JE Jr, Sherbourne CD: The MOS 36-item short-form health survey (SF-36). I. Conceptual framework and item selection. Med Care. 1992; 30(6): 473-83. PubMed Abstract

22. Brooks R: EuroQol: The current state of play. Health Policy. 1996; 37(1): 53-72. PubMed Abstract | Publisher Full Text

23. Weaver TE, Laizner AM, Evans LK, et al:: An instrument to measure functional status outcomes for disorders of excessive sleepiness. Sleep. 1997; 20(10): 835-43.

PubMed Abstract

24. Nim RD, Kapur VK, Redline-Bruch J, et al.: An Economic Evaluation of Home Versus Laboratory-Based Diagnosis of Obstructive Sleep Apnea. Sleep. 2015; 38(7): 1027-37.

PubMed Abstract | Publisher Full Text | Free Full Text |

Faculty Opinions Recommendation

25. Leger D, Bayon V, Laaban JP, et al.: Impact of sleep apnea on economics. Sleep Med Rev. 2012; 16(5): 455-62

PubMed Abstract | Publisher Full Text

26. Tarasiuk A, Reuveni H: The economic impact of obstructive sleep apnea. Curr Opin Pulm Med. 2013; 19(6): 639-44.

PubMed Abstract | Publisher Full Text

27. Kirsch DB, Yang H, Maslow AL, et al:: Association of Positive Airway Pressure Use With Acute Care Utilization and Costs. J Clin Sleep Med. 2019 15(9): 1243-50.

PubMed Abstract | Publisher Full Text | Free Full Text |

Faculty Opinions Recommendation

28. Albarrak M, Banno K, Sabbagh AA, et al:: Utilization of healthcare resources in obstructive sleep apnea syndrome: A 5-year follow-up study in men using CPAP. Sleep. 2005; 28(10): 1306-11.

PubMed Abstract | Publisher Full Tex

29. Bahammam A, Delaive K, Ronald J, et al.: Health care utilization in males with obstructive sleep apnea syndrome two years after diagnosis and treatment. Sleep. 1999; 22(6): 740-7.

PubMed Abstract | Publisher Full Text

30. Banno $\mathrm{K}$, Manfreda J, Walld $\mathrm{R}$, et al:: Healthcare utilization in women with obstructive sleep apnea syndrome 2 years after diagnosis and treatment. Sleep. 2006; 29(10): 1307-11.

PubMed Abstract | Publisher Full Text

31. Cai $\mathrm{Q}$, Tan $\mathrm{H}$, Singer J: Impact of positive airway pressure among obstructive sleep apnea patients. Am J Manag Care. 2012; 18(6): e225-33. PubMed Abstract

32. Chhatre S, Chang YHA, Gooneratne NS, et al:: Association between adherence to continuous positive airway pressure treatment and cost among medicare enrollees. Sleep. 2020; 43(1): zsz188.

PubMed Abstract | Publisher Full Text | Faculty Opinions Recommendation

33. Dde Vries GE, Hoekema A, Vermeulen KM, et al:: Clinical- and
Cost-Effectiveness of a Mandibular Advancement Device Versus Continuous Positive Airway Pressure in Moderate Obstructive Sleep Apnea. J Clin Sleep Med. 2019; 15(10): 1477-85.

PubMed Abstract | Publisher Full Text | Free Full Text

Faculty Opinions Recommendation

34. Hoffman B, Wingenbach DD, Kagey AN, et al:: The long-term health plan and disability cost benefit of obstructive sleep apnea treatment in a commercial motor vehicle driver population. J Occup Environ Med. 2010; 52(5): 473-7. PubMed Abstract | Publisher Full Text | Faculty Opinions Recommendation

35. Javaheri S, Caref EB, Chen E, et al.: Sleep apnea testing and outcomes in a large cohort of Medicare beneficiaries with newly diagnosed heart failure. $\mathrm{Am}$ $J$ Respir Crit Care Med. 2011; 183(4): 539-46.

PubMed Abstract | Publisher Full Text

36. Jennum $P$, Kjellberg J: Health, social and economical consequences of sleepdisordered breathing: A controlled national study. Thorax. 2011; 66(7): 560-6. PubMed Abstract | Publisher Full Text

37. McMillan A, Bratton DJ, Faria R, et al:: A multicentre randomised controlled trial and economic evaluation of continuous positive airway pressure for the treatment of obstructive sleep apnoea syndrome in older people: PREDICT. Health Technol Assess. 2015; 19(40): 1-188.

PubMed Abstract | Free Full Text | Faculty Opinions Recommendation

38. Peker Y, Hedner J, Johansson A, et al.: Reduced hospitalization with cardiovascular and pulmonary disease in obstructive sleep apnea patients on nasal CPAP treatment. Sleep. 1997; 20(8): 645-53. PubMed Abstract | Publisher Full Text

39. Tarasiuk A, Simon T, Tal A, et al:: Adenotonsillectomy in children with obstructive sleep apnea syndrome reduces health care utilization. Pediatrics. 2004; 113(2): 351-6.

PubMed Abstract | Publisher Full Text

40. Platt AB, Kuna ST, Field SH, et al:: Adherence to sleep apnea therapy and use of lipid-lowering drugs: A study of the healthy-user effect. Chest. 2010; 137(1): 102-8.

PubMed Abstract | Publisher Full Text | Free Full Text

41. Villar I, Izuel M, Carrizo S, et al:: Medication adherence and persistence in severe obstructive sleep apnea. Sleep. 2009; 32(5): 623-8.

PubMed Abstract | Publisher Full Text | Free Full Text

42. Ruiter ME, DeCoster J, Jacobs $\mathrm{L}$, et al.: Sleep disorders in African Americans and Caucasian Americans: A meta-analysis. Behav Sleep Med. 2010; 8(4): 246-59.

PubMed Abstract | Publisher Full Text

43. Jackson CL, Redline S, Emmons KM: Sleep as a potential fundamental contributor to disparities in cardiovascular health. Annu Rev Public Health. 2015; 36: 417-40.

PubMed Abstract | Publisher Full Text | Free Full Text |

Faculty Opinions Recommendation

44. Wallace DM, Williams NJ, Sawyer AM, et al:: Adherence to positive airway pressure treatment among minority populations in the US: A scoping review. Sleep Med Rev. 2018; 38: 56-69.

PubMed Abstract | Publisher Full Text | Free Full Text Faculty Opinions Recommendation

45. Wickwire EM, Jobe SL, Oldstone LM, et al:: Lower socioeconomic status and co-morbid conditions are associated with reduced continuous positive airway pressure adherence among older adult medicare beneficiaries with obstructive sleep apnea. Sleep. 2020; 43(12): zsaa122. PubMed Abstract | Publisher Full Text

46. Billings ME, Auckley D, Benca R, et al:: Race and residential socioeconomics as predictors of CPAP adherence. Sleep. 2011; 34(12): 1653-8. PubMed Abstract | Publisher Full Text | Free Full Text

47. Jackson CL, Walker JR, Brown MK, et al:: A workshop report on the cause and consequences of sleep health disparities. Sleep. 2020; 43(8): zsaa037. PubMed Abstract | Publisher Full Text | Free Full Text |

Faculty Opinions Recommendation

48. Wickwire EM: Making Dollars and Sense of SAVE. J Clin Sleep Med. 2017; 13(5): 765-6.

PubMed Abstract | Publisher Full Text | Free Full Text

49. Wickwire EM, Lettieri CJ, Cairns AA, et al:: Maximizing positive airway pressure adherence in adults: A common-sense approach. Chest. 2013; 144(2): 680-93. PubMed Abstract | Publisher Full Text 